\title{
ユーザ視点の導入による事業アイデアの質の向上
}

\section{Improvement in Quality of Business Ideas by Introducing User Perspective}

\author{
和嶋 雄一郎東京大学大学院情報学環 \\ Yuichiro Wajima Interfaculty Initiative in Information Studies, The University of Tokyo \\ ywajima@iii.u-tokyo.ac.jp \\ 熟田瞁 祐一 \\ 一橋大学大学院商学研究科 \\ Graduate School of Commerce and Management, Hitotsubashi University \\ yuichi.washidaer.hit-u.ac.jp \\ 冨永 直基 \\ 株式会社 博報堂 \\ Hakuhodo Inc. \\ naoki.tominaga@hakuhodo.co.jp \\ $\underset{\text { Kazuhiro Ueda }}{\text { 植田 }}$ \\ 東京大学大学院情報学環/科学技術振興機構 \\ Interfaculty Initiative in Information Studies, The University of Tokyo / CREST, Japan Science and Technology Agency \\ ueda@cs.c.u-tokyo.ac.jp
}

keywords: user innovation, business idea, future foresight, workshop, creativity

\section{Summary}

Previous studies of innovation have recognized that many innovations are developed by users. However, there is a risk of leaking new ideas by users who join a discussion to generate ideas. In order to avoid the risk, this study proposes a new workshop method to generate business ideas. In the workshop method, idea generators are required to discuss new business ideas based on information that is organized by users who do not join the discussion and thus never know new ideas that are created in this workshop. Idea generators who are given the user-organized information are considered to be able to create new ideas using the given information. We conducted an experiment to test this. In our experiment, participants were divided into two groups: the first group was asked to generate new business ideas based on the information with user perspective while the second group was asked to do so based on the information with engineer perspective. Performance of the first group was compared with that of the second group. Eight outside experts rated all ideas generated in terms of novelty, benefit and feasibility. The result showed that the ideas generated by the first group were rated significantly higher in terms of novelty as well as lower in terms of feasibility than the ideas generated by the second group. Furthermore, a questionnaire survey carried out to those who joined this workshop supported this finding. Our findings suggest that our workshop method is useful for bringing user perspective into actual business idea generation.

\section{1. は じめに}

企業が製品開発やサービスの開発を行う際には, 弚れ までに展開されてきているものとは異なった , 新しい価 值を有した製品やサービスに結びつくアイデアを生成す ることが求められる．すなわち，いかにイノベーション (innovation) を起こし , 従来とは違う新たな製品やサービ スを開発していくかということは, 企業にとって大変重 要な課題となっている [丹羽 06].

これまでの研究では，イノベーションは企業の内部の 人材 (専門家や技術者)，いわゆる供給側によってもたら されるとされてきた．しかし，供給側からではなく，ユー ザ側からも新しく斬新なアイデアが生成されることが明 らかになってきている．このようなユーザイノベーショ ンの有名な事例として , サランラップに関するエピソー ドがあげられる[旭化]「ポリ塩化ビニリデンのフィルム」 (のちのサランラップ) は元々軍用として , 銃や弾丸を湿
気から守るための包装フィルムに利用されていたが, 戦後 は, 特に用途が見つからない技術であつた . ある日 , フィ ルム製造メーカの職長 2 名の妻がフィルムに包んだレタ スをピクニックに持っていったところ，新鮮さが保たれ ていたため大変な評判になり, 乥こから食品用フィルム としてのサランラップが作られた（弚れらの職長の妻の 名前が, サラとアンであったため,「サランラップ」と名 付けられた）。

イノベーションとユーザの関係性について , [Allen 77] は, 技術者と市場 (ユーザ) 間の情報伝達者 (ゲートキー パ) の重要性を指摘している. [Allen 77] は, 新しい技術 や製品をユーザに提供するだけではなく，ユーザの要求 などを技術者に伝えることのできる，技術の知識とユー ザ視点を持ったゲートキーパという存在がイノベーショ ンをもたらすことを主張している．また，[von Hippel 88] は，技術的に斬新で,かつ商業的に成功した理化学機器 の最初の開発と重要な改良のアイデアのほとんどは, 光 
れらの機器を実際に使用していたユーザによって生み出 されていることを突き止めた . [von Hippel 88] は ,こう いったゲートキーパの樣な役割を果たす先進的なユーザ をリードユーザ (lead user) と呼び, アイデアの源泉が, 製 品開発者・研究者に代表される供給側ではなくユーザ側 にある可能性を示した . 加えて , [Washida 05, 熟田 08] は，携帯電話やスポーツ用多目的車などにおいて，商品・ 技術の新しい使い方・新しい価值についてのアイデアを 生活者であるユーザが意識的・無意識的に創造している ことを明らかにしている

実際にユーザの視点を取り入れて新製品の開発を行っ ている例も見られる.[Lilien 02]では,3M 社の協力の下， 同社のアイデア創造プロジェクトから生まれた製品コン セプトについて事例調査か実施された . 弚の結果, $3 \mathrm{M}$ 社 の従来の商品開発プロジェクトにおいて技術者のアイデ アから生まれた商品コンセプトよりも，リードユーザの アイデアによる製品コンセプトの方が独自性があり，高 い売り上げに結びつくと予想されており，さらに，追加 的な製品改良に留まらない, 新しい製品ラインを構成す るものと評価されていることが示された．また，Dellで は, Idea Storm と呼ばれるサイトが運営されており，ネッ 卜を利用してユーザか製品の改良や新しい製品のアイデ アを提案できるようになっている，同樣に，無印良品で は, ソファーやポータブルランプなどー部の新しい製品 が,ユーザによって提案されたアイデアをベースに開発さ れており，弚のデザイン性や性能が高く評価されている. 弚のほかにも, adidas, BBC, BMW, Boeing, Ducati など が同じようにユーザのアイデアを商品開発に利用してい る [Sawhney 05, Ogawa 06, Piller 06, Berthon 07, Fuchs 11] . これらの企業におけるユーザを製品開発に参加させ る取り組みは, 特定の製品に対して高い興味を持つユー ザや積極的に製品の開発に関わろうとしているユーザ， いわゆるリードユーザを対象にして行われている．すな わち，リードユーザに企業側からアプローチし，技術に 関する情報の提供を行って, リードユーザを樣々な形で サポートしながらアイデア生成を行わせている．つまり， リードユーザに技術的なサポートをすることで, ゲート キーパのような存在にし，アイデア生成を行わせる手法 だと解釈できる .

このように, ユーザ視点が新しく独自性のあるアイデ アをもたらすことを報告した研究は上記にあげた例以外 にも数多く存在する.一方, 専門家や技術者のアイデア は, ユーザのアイデアに比べて，独自性が低くなること が知られており [Kristensson 04]，多くの技術者が関わる 企業内での製品アイデア生成では，独自性が低いアイデ アが生成される傾向にある。したがって，企業において 独自性の高いアイデアを生成するには，アイデア生成時 にユーザ視点をいかにして反映させるかが重要になって くる.

しかし，企業における製品開発のためのアイデアを生
成する際に，常にユーザを直接参加させるというのは現 実的ではない，乥こで生成されたアイデアは, 弚の企業 の今後の方向性を決定づけるような重要なアイデアとな る可能性があり，機密性の高い情報となり得る．このよ うなアイデアが社外に流出するようなことが起これば， 企業は大きな損害を受けることになる .ユーザをアイデ ア生成に直接参加させるということは, ユーザ視点を導 入できるという利点の裏に, 情報漏洩というリスクを抱 えていると言える。

弚れでは, ユーザをアイデア生成に直接参加させるこ となく，ユーザ視点を反映したアイデアを生成する方法 は存在しないのであろうか. 兴の可能性を検討するため， 本研究ではアイデアの生成手法の一つである「未来洞察 手法」に着目した [熟田 07] . 未来洞察手法とは, ワーク ショップ形式で行われる近未来 (5 10 年先) の社会変化 を考慮に入れたアイデア生成の手法である．この方法は， 生活者像が反映された近未来予兆のステートメントであ る「社会変化シナリオ」を複数作成すると同時に，現在 の産業・技術視点から考えられる発展の可能性を記した 「技術発展シナリオ」を複数作成する。乥して，この社会 变化シナリオと技術発展シナリオを乥れ掛け合わせ て, 未来の社会変化を想定した新しい事業を強制発想さ せる(社会変化シナリオと技術発展シナリオを掛け合わ せ，光こから強制発想してアイデアを生成させる方法は， インパクトダイナミクスと呼ばれる）. [熟田 09] らは， 未来洞察手法を用いた実業の発想支援ワークショップに おいて, 科学技術の発展と社会変化の関係性を考慮に入 れたアイデア生成を行わせた，弚の結果，専門領域同士 の相互依存性や爫の外部性要素がうまく取り込まれたア イデアの生成が行われたことを報告している．また，ア メリカ国防兵站局では，この未来洞察手法を使用した社 会変化予測システムが運用され, 物資の調達や配送の方 針を考える際に利用されている [Schoemaker 13] .

本研究では, ユーザをアイデア生成に直接参加させる ことなく，ユーザ視点を取り入れたアイデア生成を可能 にするために，この未来洞察手法における「技術発展シ ナリオ」の作成方法に特に着目した . 未来洞察手法にお いては, 社会変化シナリオと技術発展シナリオを用いた インパクトダイナミクスによって事業アイデアを生成す る. 弚の際に用いられる技術発展シナリオは, 文字通り 「技術の発展」のシナリオであるため，技術情報を正しく 理解している (理解できる) 技術者に关の作成が依頼さ れることが多かった . 兴のため, 従来の未来洞察手法で は，技術発展シナリオは技術者視点で作成されたものが 利用されていた，乥れに対して本研究では，従来の技術 者視点の技術発展シナリオではなく, ユーザ視点の技術 発展シナリオを与えることを考えた . 技術情報を正しく 理解でき, かつユーザの視点を持つゲートキーパやリー ドユーザが技術発展シナリオを作成すれば，ユーザ視点 の技術発展シナリオをワークショップ参加者に提供する 
ことが可能になる.技術発展シナリオにユーザ視点が反 映されていれば，インパクトダイナミクスによって生成 されるアイデアにもユーザ視点が反映され，独自性の高 いアイデアが生成される可能性があると考えられる．ま た , ワークショップ実施者側がまとめる技術発展シナリ オはワークショップ開催前にワークショップ参加者以外に よって作成される．この技術発展シナリオを作成するに あたり利用される情報は，すべてが公開されている情報 であるため，弚の情報には機密事項は存在しない．加え て，技術発展シナリオ作成者は，ワークショップに参加 することがないため，ワークショップにおいて生成され たアイデアに触れることはない，つまり，技術発展シナ リオ作成者はアイデア生成に関わる機密事項に一切触れ ることはない．したがって，この技術発展シナリオの作 成にユーザを参加させることに関しては，情報漏洩とい うリスクは存在しないことになる .

つまり, 未来洞察手法でのインパクトダイナミクスに 使用する技術発展シナリオをユーザ視点で作成すること によって，「情報漏洩リスクの回避」と「ユーザ視点の導 入」を同時に行うことが可能になり，炎の結果，企業に おけるアイデア生成においても，独自性の高いアイデア が生成されることが期待できる．乥こで本研究では，未 来洞察手法において, ユーザ視点を含む技術発展シナリ オと含まない技術発展シナリオとで, 生成される事業ア イデアの質に差が生じるのかどうかを分析し，事業アイ デア生成におけるユーザ視点の効果を示す．

\section{2. ユーザ視点を導入したアイデア生成}

本章では, まず本研究で用いられたワークショップの 手続きについて述べる (2·1 節)，次に，ユーザ視点・技 術者視点での技術発展シナリオの作成方法について述べ (2.2 節)，続いて，ワークショップで生成されたアイデア の第 3 者評定の方法 $(2 \cdot 3$ 節) と, ワークショップ参加者 に対して実施した事後アンケートについて述べる $(2 \cdot 4$ 節 ). ${ }^{* 1}$

\section{$2 \cdot 1$ 未来洞察手法を用いたワークショップ}

本研究では, 未来洞察手法 [鷲田 07] を利用してワーク ショップを行い事業アイデアの生成を行わせた .ワーク ショップには企業から 22 名が参加し,「2020 年アジア向 けスマートシティ研究開発ビジョニング」というタイト ルで開催された .ワークショップでは, 2020 年にスマー トシティによって実現される社会像 (ビジョン)，ビジネ スモデル, 兴の実現に向けた課題を考え，2020 年のアジ アにおけるスマートシティの新規事業アイデアを作成し

*1 なお , 本ワークショップは , 実際の企業での新規事業ビジョ ン策定が目的のため,関係者全員に対し守秘義務契約を結んだ 上で実施された。兴のため, ワークショップで生成されたアイ デアの内容は公表できない . したがって本論文では, 公表か許 されたアイデアの評定值を用いて分析，検討を行う。
た . 参加者は , 3〜4 名からなるチームに分けられ (合計 6 チーム)，チームを単位として事業アイデアを生成し た . 未来洞察手法では, 社会变化シナリオと技術発展シ ナリオを用意し，乥れらを利用したインパクトダイナミ クスによって事業アイデアを生成する . 具体的には，以 下の手順で事業アイデアの生成を行わせた (図 1).

作業 1 個人での社会変化シナリオの作成 (個人作業)

作業 2 チームでの社会変化シナリオの作成 (チーム作業) 作業 3 社会変化シナリオの共有と, 利用する社会変化 シナリオの選定 (全体作業)

作業 4 インパクトダイナミクスによる事業アイデア生 成 (チーム作業)

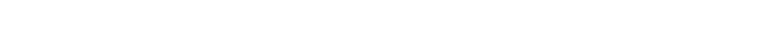
化シナリオを作成してもらった . 社会変化シナリオとは , 現在の社会の延長上からややはずれた近未来の社会像の ことで，インパクトダイナミクスによる事業アイデア生 成の際に光の事業を展開する対象を考えるためのべース となる . 社会変化シナリオは , スキャニングマテリアル と呼ばれる，新聞記事などをべースにした樣々な分野の 今後の「変化の芽」になるような情報を集めたものを参 考にして作成された (付録 B) . スキャニングマテリアル として，ワークショップ実施者側であらかじめ選定した ものを参加者に配布する . 本ワークショップでは，参加 者には事前に実施者側で選定した 143 個のスキャニング マテリアルを配布した . 参加者は , すべてのスキャニン グマテリアルに目を通し，いくつかのスキャニングマテ リアルを組み合わせて , 個人ごとに2〜3 個の社会変化シ ナリオを考えた，さらに，個人で作成した社会変化シナ リオをワークショップ時に持ち寄って議論を行い, チー ムごとに3つにまとめてもらった 。

次に , ワークショップ参加者全員で , チームごとに作 成した社会变化シナリオを共有した，弚の社会变化シナ リオの中から，ワークショップ参加者全員でインパクト ダイナミクスて使用する社会変化シナリオを 8 つ選んだ .

最後に，選ばれた社会変化シナリオとワークショップ主 催側で用意した技術発展シナリオ (詳細は $2 \cdot 2$ 節) を用 いたインパクトダイナミクスによって , 2020 年のスマー トシティの新規事業ビジョン策定，ならびに光のような 新事業が未来社会に及ぼす影響についての事業アイデア を生成してもらった。

ワークショップ終了時に, ワークショップ参加者に対し て , 今回のワークショップについての事後アンケートを 実施した。

\section{$2 \cdot 2$ ユーザ視点・技術者視点の技術発展シナリオ}

$\S 1$ 技術発展シナリオの作成手順

技術発展シナリ才は，現在提案されている技術から考 えられる発展の可能性を記したもので，インパクトダイ ナミクスによってアイデアを生成する際に技術的な側面 についてのベースとなる情報を与えるものである .この 


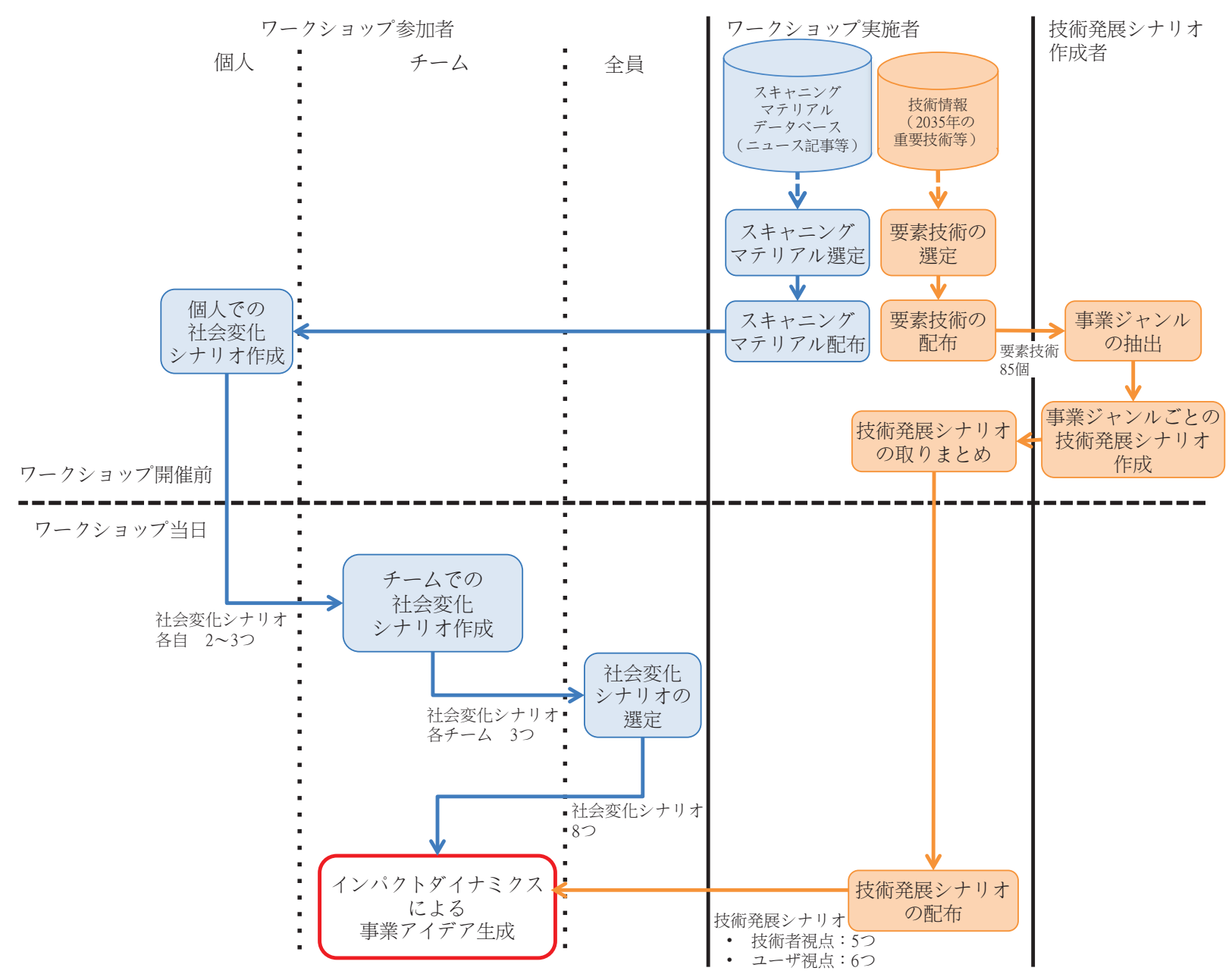

図 1 未来洞察手法によるワークショップ

技術発展シナリオはワークショップ実施側で事前に用意 され，ワークショップ当日に参加者に提供される．技術 発展シナリオは, ワークショップのテーマに関連する技 術情報を適切に理解できる人物に作成を依頼する。通常， 技術発展シナリオの作成では，はじめにワークショップ 実施者側が「技術情報（要素技術）の選定」を行う．次 に技術発展シナリオ作成者に「事業ジャンルの抽出」を 行ってもらった後,「技術発展シナリオの作成」を行って もらう.

要素技術の選定: 技術発展シナリオを作成する際に，何 もない状態から技術発展シナリオを考えることは，作成 者に大きな負担を与えることになる．关の負担を軽減す るために, あらかじめワークショップ実施者側で , ワー クショップのテーマに関連する技術情報を選定しておき， 弚れを技術発展シナリオ作成者に与える.技術発展シナ リオ作成者に与えられる技術情報は，一般に公開されて いる技術情報から，ワークショップのテーマに関連した ものを選び出し，兴の中に含まれている技術領域を列挙 したものである (これを要素技術と呼ぶ . 要素技術の例 については付録 A を参照) . 要素技術は, ワークショップ 実施側の数名でできるだけ多く (100 個前後が目安) 選 定し，技術発展シナリオ作成者に与えられる。
事業ジャンルの抽出: 技術発展シナリオ作成者には，ま ずはじめに，与えられた要素技術について，技術が発展 していく上で関わり合いが深くなると考えられる要素技 術を組み合わせて今後のサービスや事業を考えてもらう． 要素技術の組み合わせで形作られるサービスあるいは事 業を，以下では事業ジャンルと呼ぶ .

技術発展シナリオの作成: 次に, 事業ジャンルごとに 1 つの技術発展シナリオを作成してもらう . 事業ジャンご とに光こに含まれる要素技術をもとにして、これらの要 素技術がこうなっているのだから，近い未来はこうなる はずだ」といった形で技術発展シナリオを作成してもら う．技術発展シナリオは，「背景」,「具体的な生活者像」， 「必要とする技術」「展開されるビジネス」「フラクチャー ポイント (このシナリオが成立するために必要不可欠な ブレイクスルー)」の5つの視点で考えてもらい, 弚れ

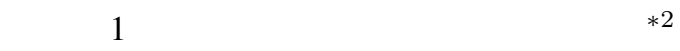

\footnotetext{
$* 2$ 複数人で技術発展シナリオの作成を行う際には, まず全員で 事業ジャンルの抽出を行う. 兴の後，事業ジャンルごとに担当 者を 1 名決め, 個別に技術発展シナリオの作成を行う. 完成 した技術発展シナリオについては意見の集約などは行わず，各 人が作成した技術発展シナリオを単純に束ねたものをワーク ショップで利用する．作成者の負担を考え，技術発展シナリオ の作成は複数人で行われることが多い.
} 
$\S 2$ ユーザ視点・技術者視点での技術発展シナリオ作成 方法

これまでの未来洞察手法を用いたワークショップでは, 要素技術を適切に理解できる技術者に技術発展シナリオ の作成を依頼していたため，技術視点の技術発展シナリ 才を利用していたと言える.本研究では, 技術発展シナ リオにユーザ視点が取り込まれていれば，インパクトダ イナミクスでのアイデア生成過程において，技術者視点 だけで作られた技術発展シナリオを用いる場合とは別の 要素が与えられ，結果的に，生成されるアイデアにも別 の評価がなされると仮定し, ユーザ視点による技術発展 シナリオと技術者視点による技術発展シナリオの光れ光 れによるインパクトダイナミクスの結果を比較した .

ユーザ視点の技術発展シナリオの作成は, ユーザの視 点を持つだけではなく，要素技術を適切に理解できる人 に依頼する必要がある．弚こで，この条件を満たす人物， いわゆるゲートキーパもしくはリードユーザと思われる 人に作成を依頼した . 具体的には, スマートシティに関 連する技術を理解することのできるの知識を持ち，加え て社会とユーザ動向のいずれも理解した上で事業主視点 をもった人 (経営学と組織論を専門とする研究者 1 名) に技術発展シナリオの作成を依頼した ${ }^{* 3}$.これに対して， 技術者視点の技術発展シナリオは, 実際の企業において ICT の技術者として製品開発を行っている4 名に作成を 依頼した . 以降，前者をユーザ視点の技術発展シナリオ， 後者を技術者視点の技術発展シナリオと呼ぶ .

本研究で実施したワークショップにおいては，ワーク ショップ実施側の 3 名が , 現在提案されている近未来に 対する技術情報の資料 (未来工学研究所の $「 2035$ 年の重 要技術」[文部 05]) から関連する 85 個の要素技術を選定 し，光れを技術発展シナリオの作成者に与えた。技術発 展シナリオ作成者（経営学と組織論を専門とする研究者 ならびに ICT 技術者) には，与えられた要素技術を組み 合わせて事業ジャンルを作成してもらった後，事業ジャ ンルごとに技術発展シナリオを作成してもらった，弚の 結果，技術者視点の技術発展シナリオが $5 つ$, ユーザ視 点の技術発展シナリオが 6 つ作成された.$* 4$.

本研究では，インパクトダイナミクスで使用する技術

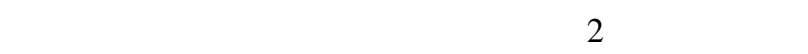
クショップを実施した . A グループには技術者視点の技

\footnotetext{
*3 本研究で実施したワークショップのテーマでのユーザとは, スマートシティで生活する人々を意味する. 兴のため, スマー トシティに関する技術や情報か理解できることに加えて，コ ミュニティー問題に関しての実践的な知識と経験を持ち,さら に，光のサービスをコミュニティでどのようにマネージするの かという視点を持つ人物に技術発展シナリオの作成を依頼する のが適当と考えられる. 弚のため, 経営学と組織論を専門とす る研究者にユーザ視点の技術発展シナリオの作成を依頼した。

*4 技術視点の技術発展シナリオの作成では, 事業ジャンルの作 成は ICT 技術者 4 名で行い, 弚の後事業ジャンルごとに担当 者 1 名を決め, 個々に技術発展シナリオを作成した .したがっ て，ユーザ視点・技術視点のどちらも，1 つの技術発展シナリ 才を担当者 1 名が単独で作成している. 弚のように作成された 技術発展シナリオを単純に束ねて，技術発展シナリオとした。
}

術発展シナリオを， B グループにはユーザ視点の技術発 展シナリオを与え，インパクトダイナミクスよる事業ア イデア生成を行わせた(なお，インパクトダイナミクス に用いた社会変化シナリオは A , B グループともに同じ ものである) .

\section{$2 \cdot 3$ アイデアの第 3 者評定}

A グループ (技術者視点の技術発展シナリオが与えら れたグループ : 3 チーム合計 11 名 ) , B グループ (ユー ザ視点の技術発展シナリオが与えられたグループ: 3 チー 厶合計 11 名) の光れ光れが作成した社会変化シナリオと 事業アイデアを，マーケティング実務者 4 名，有識者 4 名 (情報工学, 都市計画, イノベーション, 経営の各分野 の専門家) の合計 8 名に評定してもらった . 評定項目は， 心理学や社会心理学の関連研究のレビューから生成され， かつアイデアを評定する観点として多くの先行研究で用 いられている，独自性，有用性，実現可能性の3つとし た [Amabile 05, Franke 06, Kristensson 04, Moreau 05] .

・独自性 : 内容がどのくらい独自で面白いか

-有用性 : 内容が未来の社会にとってどのくらい有用か

・実現可能性 : 内容がどのくらい実現可能か

評定は，5がもつとも評定が高く(独自性，有用性，実

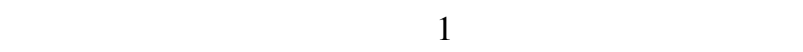
に，5〜1の 5 段階で行ってもらった. 乥して，A グルー

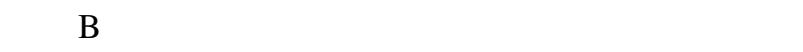
する評定の平均を比較した .

\section{$2 \cdot 4$ 事後アンケート}

チームでアイデア生成を行う場合，メンバー同士でど れぐらい同調・合意して議論が進められているかが，ま た，議論しているアイデアに対するメンバー自身の評価 が, 生成されるアイデアの質に影響を与えることが知ら れている [Stroebe 94] . 与えられた技術発展シナリオの 違いによって，メンバーの合意度，アイデアに対する評 価に差があった場合，生成されたアイデアの質に影響を 与える可能性がある. 弚こで, 第三者によるアイデア評 定に加えて， ワークショップ参加者 (A グループ 11 名 B グループ 11 名 , 合計 22 名) に対して事後アンケート を実施し，A グループと B グループの結果を比較するこ とで, 与えられた技術発展シナリオの違い（技術者視点 かユーザ視点か) による，メンバーの合意度，アイデア に対する評価の違いを分析した .アンケートでは，事業 アイデアを生成する際のチーム作業に関して，以下の 4 項目を回答してもらった (1〜 5の 5 段階, 数字が高いほ ど当てはまることを意味する) 。

・Q1 : 本日のご自分のチームで作ったアイデアは,チー ムメンバー全員が合意して作られたと思いますか.

・Q2: 本日のアイデアを作る議論全体は，あなたにとっ て満足でしたか。

・Q3 : 本日ご自分のチームで作ったアイデアを，あな 
表 1 社会変化シナリオに対する評価

\begin{tabular}{lllr}
\hline \hline \multicolumn{4}{l}{ グループ平均 (SD) } \\
& $\mathrm{A}$ & $\mathrm{B}$ & $\mathrm{U}$ 值 $(p$ 值 $)$ \\
\hline 独自性 & $3.03(0.67)$ & $2.64(0.55)$ & $51(.37)$ \\
有用性 & $3.39(0.30)$ & $2.96(0.73)$ & $52(.33)$ \\
実現可能性 & $3.35(0.57)$ & $3.19(0.60)$ & $47.5(.56)$ \\
\hline
\end{tabular}

たは面白いと思いますか．

・Q4 : 本日ご自分のチームで作ったアイデアを，あな たは現実味があると思いますか．

光れ光れの質問は，ワークショップ参加者が感じた，Q1： 合意度，Q2：満足度，Q3：アイデアの面白さ，Q4：ア イデアの現実味，についての測定項目となっている。

\section{3. 評 定 結 果}

\section{$3 \cdot 1$ 社会変化シナリオ}

社会変化シナリオに関しては, 1 チーム当たり 3 個 , 合 計 18 の社会変化シナリオが出された . A グループの 9 個の社会変化シナリオ, B グループの 9 個の社会変化シ ナリオについての評定結果を表 1 に示す．独自性，有用

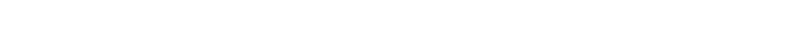
を調べるために , ケンドールの一致係数 W を計算した ところ，独自性で 0.377 , 有用性で 0.357 ，実現可能性で 0.331 という数值が得られ，いずれも $0.1 \%$ 水準で有意で あった .このことから，いずれの評定項目においても，評 定者による評定の違いはなかったと言える.

独自性，有用性，実現可能性の光れぞれの評定値につ いて，グループ間で差があるかどうかを検定した（なお， データ数が少ないため, ノンパラメトリックの検定であ るU 検定を実施した）。表 1 に示した通り，独自性，有 用性 , 実現可能性のいずれにもグループ間で有意な差は 見られなかった .

社会変化シナリオの作成は, 技術発展シナリオが与え られる前に実施されている．つまり，Aグループと B グ ループが同じ条件で作成していることになる，独自性， 有用性，実現可能性の評定にグループ間の差がみられな かったことから, 両グループのワークショップ参加者の アイデア生成の能力に差はなかったと考えられる .

\section{$3 \cdot 2$ 事業アイデア}

インパクトダイナミクスによって生成された事業アイ デアに関しては, $\mathrm{A}$ グループは 9 アイデア (チーム当た り 3 アイデア) , B グループは 11 アイデア (チーム当た り $3 \sim 4$ アイデア) が出された . 独自性, 有用性, 実現可 能性の弚れ攵れの評定值の評定者間の一致度を調べるた めに，ケンドールの一致係数 W を計算したところ，独自 性で 0.246 , 有用性で 0.394 , 実現可能性で 0.299 という 数值が得られ，いずれも $0.1 \%$ 水準で有意であった .この
表 2 事業アイデアに対する評価

\begin{tabular}{|c|c|c|c|}
\hline & \multicolumn{2}{|c|}{ グループ平均 (SD) } & \multirow[b]{2}{*}{$\mathrm{U}$ 値 ( $p$ 値) } \\
\hline & A & B & \\
\hline 独自性 & $2.44(0.40) \quad 2$ & $2.98(0.58)$ & $21.5(.032 *)$ \\
\hline 有用性 & $3.38(0.28) \quad 2$ & $2.99(0.87)$ & $59.5(.464)$ \\
\hline 実現可能性 & $3.51(0.31) \quad 2$ & $2.81(0.54)$ & $86.5(.003 * *)$ \\
\hline \multicolumn{4}{|c|}{ 表 3 事後アンケート結果 } \\
\hline \multicolumn{4}{|c|}{ 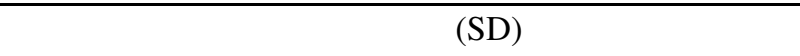 } \\
\hline & A & $\mathrm{B}$ & $\mathrm{U}$ 値 $(p$ 值) \\
\hline Q1. 合意度 & $4.28(0.62)$ & $4.64(0.48)$ & $42(.28)$ \\
\hline Q2. 満足度 & $3.91(1.00)$ & $4.10(0.51)$ & $56.5(.80)$ \\
\hline \multicolumn{4}{|l|}{ Q3. アイデア } \\
\hline の面白さ & $3.73(0.75)$ & $4.55(0.50)$ & $26(.023 *)$ \\
\hline \multicolumn{4}{|l|}{ Q4. アイデア } \\
\hline の現実性 & $3.55(0.50)$ & $3.10(0.67)$ & $82(.18)$ \\
\hline
\end{tabular}

ことから，いずれの評定項目においても，評定者による 評定の違いはなかったと言える。独自性，有用性，実現可 能性の关れ光れの評定值について, グループ間で差があ るかどうかを調べるためにU 検定を行った（表 2)．弚の 結果，独自性に関しては, A グループ (2.44)よりも B グ ループ (2.98)の方が, 評点が有意に高かった $(p=.032 *)$. また実現可能性に関しては, 逆にAグループ (3.51)の方

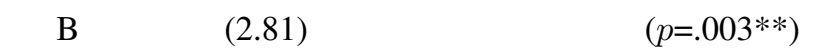

この結果は, ユーザ視点の技術発展シナリオに基づい て考えた B グループのアイデアは独自性が高かったのに 対して, 技術者視点の技術発展シナリオに基づいて考え たAグループのアイデアは実現可能性が高かったことを 示している.この結果から，ユーザ視点が加わることで アイデアの独自性が高くなるということが示唆された .

\section{$3 \cdot 3$ 事後アンケート}

グループごとの各質問に対する平均点は表 3 のように なった . また , グループ間での各質問に対する回答に差 があるかどうかを調べるためにU 検定を行った（表 3 ) 。 $\mathrm{Q} 1$ の合意度と Q2 の満足度に関しては, 両グループとも に高い評価となり，どちらの質問でもグループ間には統 計的に有意な差は見られなかった。また，Q4のアイデア の現実性に関しても，グループ間に統計的に有意な差は 見られなかった .Q3 のアイデアの面白さに関しては , B グループ (4.55) の方が A グループ (3.73) よりも統計的 に有意に高い回答となっていた $\left(p=.023^{*}\right)$.この結果か ら，ユーザ視点の技術発展シナリオを与えることによっ て，アイデア作成者自身が面白いと感じるアイデアを生 成できていたことが示唆された . 


\section{4. 総 合 考 察}

社会変化シナリオの独自性, 有用性, 実現可能性に関 しては, グループによる差は認められなかった . このこ とは，創造的な（独自なあるいは有用な）アイデアを生 成する能力の点では, グループによる差がなく，弚の点 で各チームがほぼ等しく構成できていたことを示唆する 一方，インパクトダイナミクスによる事業アイデア生成 に関して言えば，独自性については，A グループよりも B グループの方が , 評定值が有意に高かったのに対して 実現可能性については, 逆にB グループよりも A グルー プの方が , 評定值か有意に高かった .つまり，ユーザ視点 の技術発展シナリオに基づいて考えた B グループのアイ デアは独自性が高かったのに対して，技術者視点の技術 発展シナリオに基づいて考えた $\mathrm{A}$ グループのアイデアは 実現可能性が高くなった .このことは，実現可能性にあ まり捉われずにアイデアをより独自性の高いものにする には，アイデアを考える際にベースとなる情報にユーザ 視点を導入することか効果的なことを示唆している．ま た，事後アンケートの結果から，ユーザ視点の技術発展 シナリオが与えられた方が自分の生成したアイデアをよ り面白いと評価していることがわかった .

アイデア評定の結果ならびにアンケート結果の両者よ り，ユーザ視点で作成された技術発展シナリオを用いた 方が, アイデアが独自性が高く，かつ面白いと感じられ るものになり，技術者視点で作成された技術発展シナリ 才を用いた方が，アイデアの実現可能性が高くなる可能 性が示唆された。

ここまで，アイデアを考える際に利用する情報の違い (技術者視点の情報であるか，ユーザ視点の情報である か）によって，生成されたアイデアの評価が異なること を示した．これは，アイデア生成を始める前の技術周辺 情報の整理の仕方や弚の内容が, 生成されたアイデアの 評価に影響する可能性を示したと言える．アイデアを考 える際に利用される情報（いわば，アイデア生成のため の入力) を変えるだけで, 生成されたアイデア (いわば， アイデアという出力) の質か変化し得ることを示した点 に，本論文の大きな貢献があると考えられる。では，ア イデアを考える際に利用される情報の違いは, アイデア 生成にどのような影響を与えているのであろうか．以降 では,「議論の方向性」「技術発展シナリオ作成における 視点の違い」に着目し，アイデアを考える際に利用され る情報の違い（技術者視点とユーザ視点で作成された情 報の違い) がもたらす影響を考察していく．

\section{$4 \cdot 1$ 議論の方向性の分析}

ここでは，技術者視点が与えられた場合と，ユーザ視 点が与えられた場合とで, ワークショップで実際に行わ れた議論の視点や方向に違いが見られるかどうかについ て分析した。
アイデア生成における議論の性質に関しては, 大きく 分けて「収束的な議論」と「拡散的な議論」の 2 つがあ るとされている [Guilford 67]. 収束的な議論においては， アイデア生成を行う際に，提示されている数多くある情 報をまとめる行為が中心となる．製品を完成させるため には，高いレベルの技術や关の知識が必要になるため，収 束的な議論を行うことで，光れらの技術や知識の集約と 整理が促進され，信頼性の高い製品の開発が可能になる というメリットがある [Vincenti 90] . そのため, 製品の 信頼性を重視しがちである技術者は収束的な議論を行い やすいと考えられる。しかし，弚ういった技術者視点から の収束的な議論は, 視野を狭め, 他の可能性に目を向け るという行為の妨げになるという報告もある [von Hippel 94]. 一方，拡散的な議論や思考は，ブレインストーミン グなどで用いられる考え方で, 数多くのアイデアを手当 たり次第ひねり出すような議論や思考である。樣々な視 点を組み合わせることによって，今まで考えを巡らして いなかったような広い視野からアイデアを生成すること が可能になる . 技術者とユーザのアイデア生成プロセス に関して，技術者は今ある技術的な情報について関係性 の高いものを組み合わせてアイデアを生成しているのに 対して，ユーザは今ある技術的な情報の関係性にはあま り注目せず，関係性の低い情報についても考慮する傾向 があることが指摘されている [Kristensson 04] .

これらを考え合わせると，技術者視点でのアイデア生 成では,これまでの情報をまとめるような収束的な議論 が起こりやすく，また，ユーザ視点のアイデア生成では， 新しい視点が積極的に取り入れられることによって拡散 的な議論が起こりやすいと考えられる．

弚こで, 事業アイデア生成のチーム作業に関して，光 こで行われた議論がどのようなものであったかについて， 独立の観察者に観測してもらった。観察者は, 会話分析 の経験を持つ心理学・認知科学の 6 名の研究者とし, 各 チームに 1 名配置した . 観察者には, 議論の方向性に関 するチェックシートとストップウォッチを配布した . 観

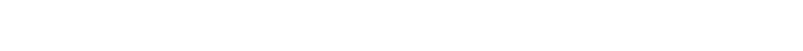
テーブルの横（チーム全員の声か聞こえる距離）に座り， 観測者弚れ光れがストップウォッチで時間を確認しなが ら，5 分ごとに光の時間での「議論の拡散・収束」,「議 論の方向性」,議論の変化」の 3 点について評価を行い， チェックシートに記入していった . 以下がチェックシート の記入項目となる .

・議論の拡散・収束 乥の時間帯の議論では, 主に，

a : トピックやアイデアが増加していた

$\beta$ : トピックやアイデアが減少していた

Y ：トピックやアイデアに変化がなかった，あるい は上記のどちらとも判断しがたいものだった

・議論の方向性 そ時間帯の議論は, 主に， 
表 4 議論の方向の分析

\begin{tabular}{lrr}
\hline \hline & $\mathrm{A}$ & $\mathrm{B}$ \\
\hline 拡散指数 & 0.47 & 0.62 \\
So What 指数 & 0.41 & 0.78 \\
変化指数 & 0.39 & 0.34 \\
\hline
\end{tabular}

a :「乥れで炎の後どうなるか? = So what?」だった

$\beta$ :「なぜそうなのか? = why?」だった

$\mathrm{Y}$ : 上記のどちらとも判断しがたいものだった

- 議論の変化

その時間帯の議論は, 主に，

a：乥れまでの議論から大きく変化した

$\beta$ : 谷れまでの議論の延長であった

$\mathrm{Y}$ ：上記のどちらとも判断しがたいものだった

なお, A グループの 1 つのチームでは , 途中 20 分ほ

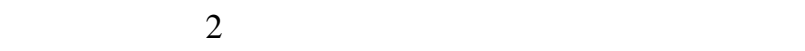
の間の議論は分析対象としなかった .ここでは，光れ光 れの $\mathbf{a}$ と の比率が分かりやすくなるように，観測され た $\alpha$ と $\beta$ の值を用いて $\alpha /(\alpha+\beta)$ を計算し , グループ 間で比較した .これら値は, 議論の拡散・収束に関して は大きいほうか議論が発散している (アイデアが増加し ている) 時間が多かったということ（議論の拡散指数）， 議論の方向性に関しては「午の後どうなるのか」という 方向に議論が進んでいる時間が多かったこと（議論のSo What 指数) になり, 議論の変化に関しては議論の流れ に変化が起こった時間が多かったこと（議論の変化指数） を示している。

議論の発散指数に関しては, A グループが 0.47 だった のに対して, B グループは 0.62 , 議論の So What 指数は, A グループが $0.41, \mathrm{~B}$ グループは 0.78 , 議論の変化指数 は A グループ 0.39 , B グループ 0.34 となった (表 4). 両 グループ合わせて 6 チームであり，統計的な検定は難し いため值の定性的な比較にとどまるが, 最も特徵的だっ たのは, 議論の So What 指数が A グループよりも B グ ループでかなり高くなったことである．また，議論のSo What 指数ほどの差は見られなかったが, 議論の発散指数 についても同樣にB グループの方が高かった .

以上より, 議論が拡散し 「なぜ光うなのか? = why?」 という事実の原因を問うよりも「炎れで光の後どうなる か? = So what?」という未来の可能性を考える局面は， A グループよりも B グループで高いことが伺える . この 結果は，技術者視点の技術発展シナリオを与えられるよ りも，ユーザ視点の技術発展シナリオを与えられた方が 拡散的な議論が起こっていたことを示唆している．事業 アイデアの評定結果と事後アンケートの結果によって示 された，第三者から見てもアイデア生成者自身から見て も B グループの方が独自性の高いアイデアを生成してい るということを考え合わせれば，与えられたユーザ視点 の技術発展シナリオの影響によって , チームでの議論に ユーザ視点が加わり, ユーザの思考傾向である拡散的な
議論や思考が促進され, 樣々な未来の可能性か議論され た結果，より独自性の高いアイデアが生成されたと推察 することができるだろう．

\section{$4 \cdot 2$ 技術発展シナリオにおける視点の違い}

本研究では，インパクトダイナミクスにユーザ視点で 作成された技術発展シナリオを用いることで, 生成され る事業アイデアの独自性が高まることを示した．ここで は，技術者視点とユーザ視点の技術発展シナリオにどの ような違いがあったのかを，実際に作成された技術発展 シナリオの内容と，技術発展シナリオの作成時の考え方 を比較して分析していく.

\section{$\S 1$ 技術発展シナリオの内容の違い}

技術発展シナリオには,「背景」,「具体的な生活者像」， 「必要とする技術」「展開されるビジネス」「フラクチャー ポイント」の 5 つの項目がある.技術視点とユーザ視点 の技術発展シナリオを比較すると，「具体的な生活者像」 に顕著な違いが見られた (付録 C). 例えば，技術者視点 の技術発展シナリオの具体的な生活者像には，「 ... 任意 の条件で検索することができる」,「 ...日常的なサービ スを受ける」，「 . . 供給元を動的に選択できるようにな る」「 $「 \ldots$ インターネットを経由して享受できるようにな る」といった記述が見られた . 技術者視点では，「新しい サービスが与えられ，利用できるようになる」という点 から生活者像を記述していることがわかる . 一方, ユ一 ザ視点の技術発展シナリオの具体的な生活者像では，「 ... すべての生活者にとって社会基盤の整備は大きな問題で ある」,「. . 安全で環境に優しいエネルギーを求めてい る」,「.. 環境負荷の小さい製品を求める」といった記 述が見られた . ユーザ視点では, 生活者の置かれている 状況や要求という点から生活者像を記述していることが わかる．これらのことから，技術発展シナリオの具体的 な生活者像は, 技術者視点では「ある特定のサービスが 与えられる」人であり, ユーザ視点では「ある状況に置 かれ，いくつかの要求を持つ」人であると解釈できる.

具体的な生活者像は, 新しい事業アイデアを展開する 対象者を考える際に重要な役割を果たしていると考えら れる.技術者視点の技術発展シナリオが想定する「サー ビスが与えられる」という生活者を満足させるためには， そのサービスを実現し，生活者に提供することが重要に なる．关のため，実現可能性を重視した事業アイデアの 生成が行われやすくなると考えられる．一方，ユーザ視 点の技術発展シナリオか想定する生活者像は, 生活者の 置かれている状況や要求が提示される. 利用者側の状況 や要求をベースとしてアイデアを生成する傾向は, ユー ザのアイデア生成時に見られる傾向であることが知られ ており [Terwiesch 09], 乥こから考えれば, 生活者の置か れている状況や要求の提示によって, ユーザのアイデア 生成時の思考傾向に近づきやすくなると想像できる . 光 のため, ユーザ視点の技術発展シナリオが与えられた場 
合, 生成されたアイデアの独自性が高くなった可能性が 考えられる。

\section{$\S 2$ 技術発展シナリオ作成時の考え方の違い}

技術発展シナリオの具体的な生活者像には，技術者視 点とユーザ視点で大きな違いか確認できた，弚の違いは， 技術者視点とユーザ視点で技術発展シナリオ作成時の考 え方の違いによってもたらされたと考えることができる． 兰こで，兴の考え方の違いを明らかにするため，A グルー

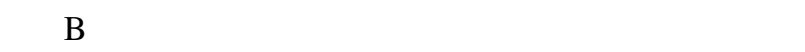
た, ICT 技術者 4 名と, 経営学と組織論を専門とする研 究者 1 名に対するインタビューを行った .インタービュー 時間は乥れ午れ 120 分であり，発話は ICレコーダに記

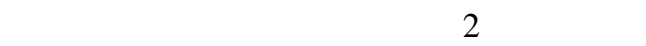

・質問 1 : 技術発展シナリオの作成で重視した点, 工 夫した点, 難しかった点

・質問 2 : 作成した技術発展シナリオがどの程度ユー ザ視点を反映していると思うか

インタビューの結果，技術者と研究者において，顕著 な違いがあったのが，技術発展シナリオ作成時のベース となる考え方であった .

質問 1 に対して，技術者は「自分の技術に対する知識 をべースにした」,「例えば，ロボットについてのアイデ アを考える場合，産業用か介護用かといった形で領域を 決め，光のドメインをベースに考えた」という発言をし ている.さらに，質問 2 に対して研究者が，「Aの技術発 展シナリオ（技術者の作成した技術発展シナリオ）に対 して実際の場面をイメージしにくい」「技術の詳細まで 理解できると現状の技術に流される」といった指摘をし ている．また技術者は,「確からしさが重要」「統計的な 情報が重要」という発言を行っていた。ここでいう確か らしさというのは，技術の実現可能性や利用可能性のこ とであり，未来の事柄に関する確からしさは，予算額の 大きいドメイン , 国際的な標準化が進んでいるドメイン に属する事柄であるという点で判断し，また，統計的な 数值を確からしさの根拠とする傾向が強いことが確認さ れた . 技術者は，自分が持っている技術知識やドメイン を発想の出発点としており，技術者のこのような考え方 は , デルファイ法 [Gordon 64] にみられるような線形な 未来変化を過程したものに近く, 現状の延長としてしか 未来を捉えられていないと思われる．

一方，研究者は質問 1 において「使用局面をイメージ した」,「具体的な社会の状況をイメージする必要があつ た」という発言をしている、研究者は乥れが使用される 社会や使用局面のイメージから発想していることが確認 された .

これらを整理すると，技術者的発想は技術やドメイン をべースに考えるため，いまある技術ドメインにフォー カスし，弚の技術がどう使えるかという発想になる. 光 のため, 現状とは異なるニーズや社会状況を思い浮かべ にくい，一方，ユーザ的発想は現状 (現実社会) から考
表 5 事業ジャンルごとの要素技術の共通数

\begin{tabular}{|c|c|c|c|c|c|c|}
\hline & & \multicolumn{5}{|c|}{ 技術者視点 } \\
\hline & $\begin{array}{l}\text { シナリオ番号 } \\
\text { (要素技術数) }\end{array}$ & $\begin{array}{l}1 \\
(7)\end{array}$ & $\begin{array}{c}2 \\
(16)\end{array}$ & $\begin{array}{l}3 \\
(9)\end{array}$ & $\begin{array}{c}4 \\
(19)\end{array}$ & $\begin{array}{c}5 \\
(9)\end{array}$ \\
\hline \multirow{6}{*}{$\begin{array}{l}\text { ユーザ } \\
\text { 視点 }\end{array}$} & $\begin{array}{c}1 \\
(18)\end{array}$ & 0 & 5 & 1 & 10 & 1 \\
\hline & $\begin{array}{c}2 \\
(10)\end{array}$ & 0 & 0 & 0 & 9 & 0 \\
\hline & $\begin{array}{l}3 \\
\text { (7) }\end{array}$ & 3 & 0 & 0 & 0 & 4 \\
\hline & $\begin{array}{c}4 \\
(10)\end{array}$ & 3 & 0 & 6 & 0 & 0 \\
\hline & $\begin{array}{c}5 \\
(19)\end{array}$ & 1 & 10 & 2 & 0 & 2 \\
\hline & $\begin{array}{c}6 \\
(20)\end{array}$ & 0 & 1 & 0 & 0 & 1 \\
\hline
\end{tabular}

えるため，現状とは異なるニーズや社会状況を考えるこ とができるという特徴があったと言える．こういった特 徵の影響を受けたため, ユーザ視点の技術発展シナリオ を用いたグループは独自性が高いアイデアを，技術者視 点の技術発展シナリオを用いたグループは実現可能性が 高いアイデアを生成したと考えられる．

\section{$4 \cdot 3$ 最 後 に}

本研究では, ユーザ視点を導入することで, 議論の方 向性やアイデアの考え方に影響を与え，アイデアの独自 性を高める効果があることを示唆した .さらに，本研究 の手法を用いれば，ユーザを直接参加させる必要がない ため，情報漏洩というリスクを抱えることなく，ユーザ視 点を反映したアイデアの生成が可能なことを示した . 本 研究では, 技術発展シナリオの作成方法の違いがアイデ ア生成にもたらす影響ついて論じてきたが，作成された 技術発展シナリオの内容に関する分析は十分であるとは いえない，本研究では，技術者視点では 4 名で5つ，ユー ザ視点では 1 名で 6 つの事業ジャンルが作成された . 光 れ光れの事業ジャンルの要素技術の組み合わせについて， 技術者視点とユーザ視点の共通性を見てみると (表 5)，技 術者視点の事業ジャンル $2,3,4,5$ は, ユーザ視点の事 業ジャンル $5,4,2,3$ と乥れ光れ共通している要素技 術が多いことか確認できた .このことから，技術者視点 とユーザ視点の要素技術の組み合わせは，ある程度は同 じ傾向を持っていることが確認できる．しかし，技術者 視点とユーザ視点では，ほとんど共通していない技術要 素の組み合わせもあり，また，弚も乥も事業ジャンル数 が異なっているなど，両者に樣々な違いが見られる．こ の違いは, 視点の違いによるものであるのか , 作成人数 の違いによるものであるのかは, 本研究では分析するこ とができていない．ユーザ視点と技術者視点の技術発展 シナリオの作成方法に関して, 事業ジャンル谷のものや， 要素技術を組み合わせる際の方法にどのような違いがあ るのかを明らかにしていくことが今後の課題の 1 つであ ると考えている.さらに , ワークショップにおけるチーム 
内での議論の方向性については調査したものの，議論の 内容については分析していない. 議論している事業アイ デアをどのような社会に対して展開することを想定して いるのか (例えば，今の社会を考えているのか, 将来訪 れると想像した社会を考えているのか）によって，生成 されるアイデアの質が異なってくると考えられる.さら に，議論の際に利用している情報の種類や关のバリェ一 ションなども生成されるアイデアの質に影響を与えてい ると考えられる.今後，アイデア生成時の発話の内容分 析を行い, 議論の内容がアイデア生成にもたらす影響を 明らかにしていくことが課題である .

\section{謝辞}

本ワークショップを実施するに当たり，越塚登教授 (東 京大学), 清水剛准教授 (東京大学), 秋田典子准教授 (千葉大学)，横山ゆりか准教授 (東京大学) にこ協力い ただきました・また本研究は,株式会社日立ソリューショ ンズならびに日本たばこ産業株式会社との共同研究とし て実施されました .ここに謝意を表します．

\section{$\diamond$ 参 考 文 献 $\diamond$}

[Allen 77] Allen, T. J.: Managing the Flow of Technology: Technology Transfer and the Dissemination of Technological Information within the R\&D Organization, MIT Press (1977)

[Amabile 05] Amabile, T. M., Barsade, S. G., Mueller, J. S., and Staw, B. M.: Affect and creativity at work, Administrative Science Quarterly, No. 50, pp. 367-403 (2005)

[Berthon 07] Berthon, P. R., Pitt, L. F., McCarthy, I., and Kates, S. M.: When customers get clever : Managerial approaches to dealing with creative consumers, Business Horizons, Vol. 50, No. 1, pp. 39-47 (2007)

[Franke 06] Franke, N., Hippel, von E., and Schreier, M.: Finding commercially attractive user innovations: A test of lead user theory, Journal of Product Innovation Management, Vol. 23, No. 4, pp. 301315 (2006)

[Fuchs 11] Fuchs, C. and Schreier, M.: Customer empowerment in new product development, Journal of Product Innovation Management, Vol. 28, No. 1, pp. 17-32 (2011)

[Gordon 64] Gordon, T. J. and Helmer-Hirschberg, O.: Report on a Long-Range Forecasting Study, RAND Corporation (1964)

[Guilford 67] Guilford, J. P.: The nature of human intelligence, New York: McGraw-Hill (1967)

[Kristensson 04] Kristensson, P., Gustafsson, A., and Archer, T.: Harnessing the creative potential among users, Journal of Product Innovation Management, Vol. 21, No. 1, pp. 4-14 (2004)

[Lilien 02] Lilien, G. L., Morrison, P. D., K. Searls, M. S., and Hippel, von E.: Performance assessment of the lead user idea-generation process for new product development, Management Science, Vol. 48, No. 8, pp. 1042-1059 (2002)

[文部 05] 文部科学省科学技術政策研究所, 科学技術政策研究所, 未来工学研究所 (編) : 2035 年の科学技術一文部科学省デルファ 个調査, 未来工学研究所 (2005)

[Moreau 05] Moreau, P. C. and Dahl, D. W.: Designing the solution: The impact of constraints on consumers' creativity, Journal of Consumer Research, Vol. 32, pp. 13-22 (2005)

[丹羽 06] 丹羽 清: 技術経営論, 東京 : 東京大学出版局 (2006)

[Ogawa 06] Ogawa, S. and Piller, F. T.: Collective customer commitment : Reducing the risks of new product development, MIT Sloan Management Review, Vol. 47, No. 2, pp. 65-72 (2006)

[Piller 06] Piller, F. T. and Walcher, D.: Toolkits for idea competitions : A novel method to integrate users in new product development,
$R \& D$ Management, Vol. 36, No. 3, pp. 307-318 (2006)

[Sawhney 05] Sawhney, M., Verona, G., and Prandelli, E.: Collaborating to create : The Internet as a platform for customer engagement in product innovation, Journal of Interactive Marketing, Vol. 19, pp. 4-17 (2005)

[Schoemaker 13] Schoemaker, P. J., Day, G. S., and Snyder, S. A.: Integrating organizational networks, weak signals, strategic radars and scenario planning, Technological forecasting \& social change, Vol. 80, No. 4, pp. 815-824 (2013)

[Stroebe 94] Stroebe, W. and Diehl, M.: Why groups are less effective than their members: On productivity losses in idea-generating groups, European review of social psychology, Vol. 5, pp. 271-303 (1994)

[Terwiesch 09] Terwiesch, C. and Ulrich, K. T.: Innovation tournaments : Creating and selecting exceptional opportunities, Cambridge, MA: Harvard Business School Press (2009)

[Vincenti 90] Vincenti, W. G.: What engineers know and how they know it, MD: Johns Hopkins University Press (1990)

[von Hippel 88] von Hippel, E.: The Sources of innovation, NY: Oxford University Press (1988)

[von Hippel 94] von Hippel, E.: Sticky information and the locus of problem solving: Implications for innovation, Management Science, Vol. 40, No. 4, pp. 429-439 (1994)

[Washida 05] Washida, Y.: Collaborative structure between Japanese hightech manufacturers and consumers, Journal of Consumer Marketing, Vol. 22, pp. 24-35 (2005)

[鷲田 07] 熟田 祐一: 未来を洞察する, NTT 出版 (2007)

[熟田 08] 熟田 祐一, 植田 一博：イノベーション・アイディアを 発生させる需要側ネットワーク伝播 構造の研究, 情報処理学会 論文誌, Vol. 49, pp. 1515-1526 (2008)

[鷲田 09] 熟田 祐一, 三石 祥子, 堀井 秀之 : スキャニング手法を 用いた社会技術問題シナリオ作成の試み, 社会技術研究論文集, Vol. 6, pp. 1-15 (2009)

[旭化] 旭 化 成: サランラップの 歴史, http://www.asahikasei.co.jp/saran/products/saranwrap/about/history.html

〔担当委員 : 西村 拓一〕

2012 年 12 月 18 日 受理

$$
\diamond \text { 付 録 } \diamond
$$

\section{A. 要素技術の例（[文部 05]より選定）}

・化石資源のクリーン利用技術

- 教育・学習支援技術

・分子・有機エレクトロニクス

・環境にやさしい効率的な物流システム技術

・循環型・低環境負荷製造技術

・公的部門のガバナンス・マネジメント

- 資源再利用

・大規模ネットワークに耐えるソフトウェア技術

・新たな交通システム技術

・ヒューマンサポート (人間の知能支援)

-革新的原子カシステム

・セキュリテイエレクトロニクス

・カーエレクトロニクス

・ゲノム・プロテオーム及び生体情報伝達機構の解明と革新的生 産技術

・IT の医療への応用

・地球環境高精度観測・变動予測技術

- 環境経済指標

・社会基盤における環境技術

・水素エネルギーシステム

・交通安全に関する技術

(以下, 省略) 
B. スキャニングマテリアルの例

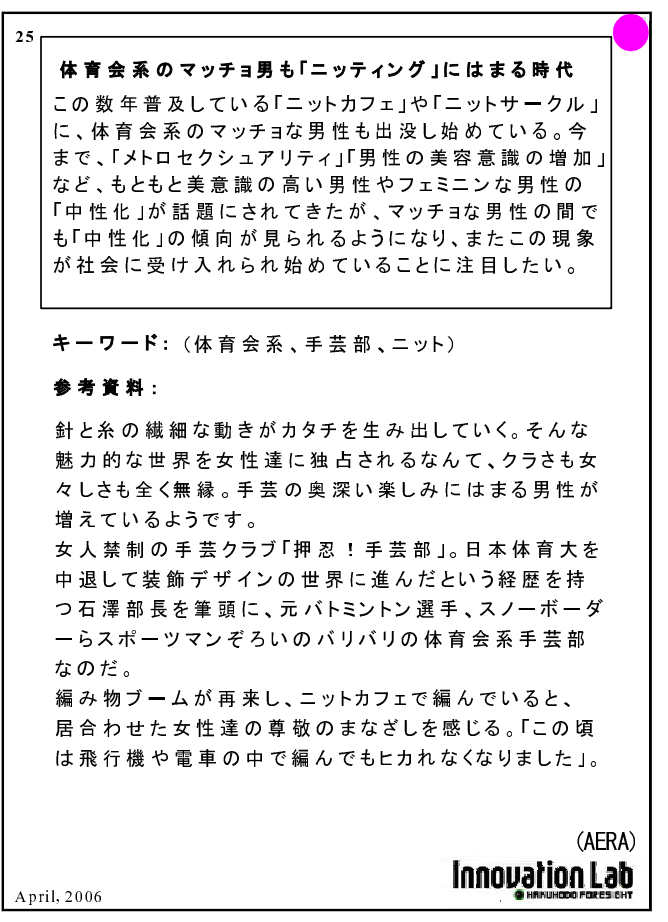

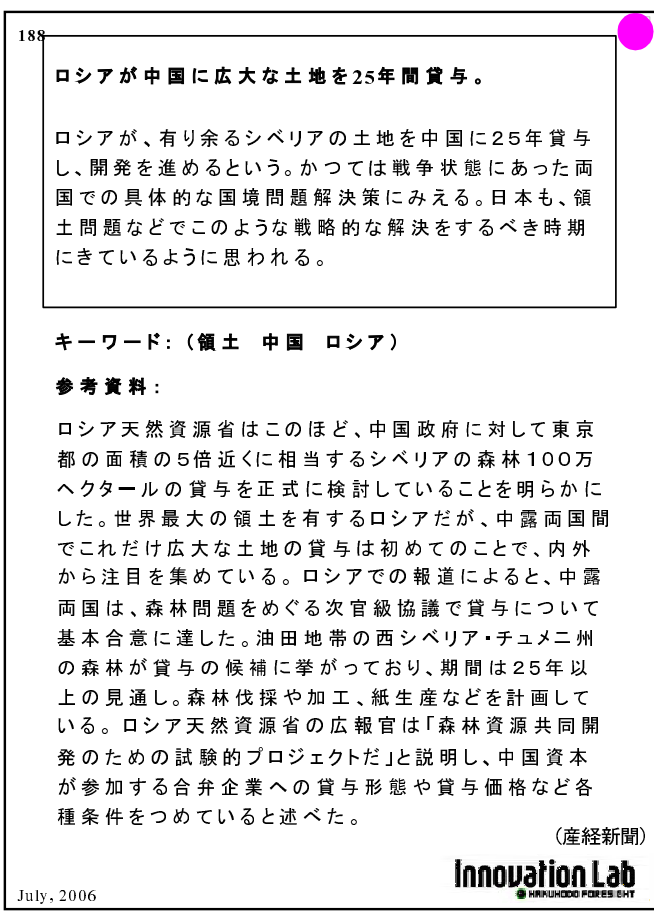

C. 技術発展シナリオ：具体的な生活者像の例

C.1 技術者視点の具体的な生活者像の例

・交通網の最適化 : 利用者の目的地に到達するまでの交通経路を， いつでもどこでも瞬時に任意の条件で検索することができる また, 交通の予約・変更等も利用者が所有する樣々なデバイス により容易に行う事ができる．ARにより，利用者を目的地へ とナビゲートできる

・あなたに最適な健康サポート：医療に関連し，日々の生活を通 じて身体的に健康を維持するために日常的にサービスの提供を 受ける. 例として, バイタルデータ・食事内容・運動内容や過 去データ・遺伝子データ・健診データ・治療データ・投薬デー 夕の他, 気温や流行疾病などの環境・社会データなどから日々 自動検診，健康アドバイスを行う，さらに必要とあれば，医師 による遠隔検診，予防接種，生活環境調整などを行う。
・電力流通への参加 : 自宅の再生可能エネルギー, 複数の電力事 業者から供給元を動的に選択できるようになる．アルゴリズム 取引を用いた電力の売買を行う生活者も現れる。

-公的サービスの完全 I T 化・住民情報管理の効率化 : 政府部門 における। T化が進み，個人認証技術と個人情報保護技術が 確立し, 税務・納税, 年金, 保険, 福祉等の住民サービスがす ベてインターネットを経由して享受できるようになる．また， 戶籍謄本や住民票 , 既往歴等の住民情報の電子化による管理が 進む。

C.2 ユーザ視点の具体的な生活者像の例

-社会の全ての人々の生活は基本的に交通・運輸, 通信, 防災, セキュリティのような社会基盤に依存している.都市部の生 活者の場合には，鉄道やバスのような交通網やセキュリティと いった側面により強く依存しているのに対して, 農村部の生活 者は道路と自動車, 光して (自然災害に対する) 防災により強 く依存しているという程度の差はあるものの，全ての生活者に といって社会基盤の整備は大きな問題である．とりわけ，近年 ではセキュリティや防災に関する関心が高まっている．

-電力供給手段を自ら保有しようとする生活者 : 例えばソーラー パネルやコジェネレーション・システムを自宅に設置しようと する生活者は、「安全で環境にやさしいエネルギー」を求めて いるという側面だけでなく, 計画停電や電力使用制限の経験を 踏まえて自ら安定的な電力供給手段を保有しようとする側面も 持っている

-「安全て環境にやさしいエネルギー」を求める生活者 : 東日本 大震災を契機として，原子力発電への依存から脱して，代替可 能エネルギーを利用すべきだと考える生活者は急速に増加して いる

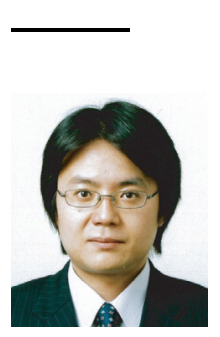

\section{者 紹}

\section{和嶋 雄一郎(正会員)}

2002 年山梨大学工学部卒業. 2009 年東京工業大学大学院 社会理工学研究科博士課程修了. 博士 (工学) . 東京工業大 学大学院教育研究支援員, 青山学院大学附置情報科学研究 センター助手を経て, 現在, 東京大学大学院情報学環特任 助教. Cognitive Science Society, 日本認知科学会各会員

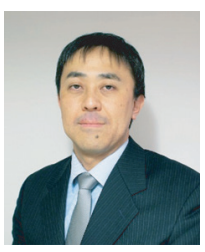

鷲田＼cjkstart祐一

2008 年東京大学大学院総合文化研究科博士課程修了. 博 士 (学術) . 一橋大学日本企業研究センター研究員 (2011 年より). 1991 年株式会社博報堂に入社 .マーケティング 職を経て, 2005 年より,同イノベーション・ラボ上席研究 員. 2011 年一橋大学准教授. 技術普及と生活者動向研究, 末来予測手法の開発などに従事。情報処理学会, 日本認知 科学会, 組織学会各会員.

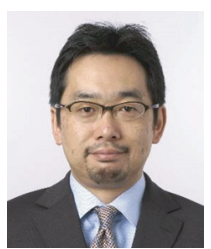

\section{冨永 直基}

1984 年筑波大学社会工学類卒業. 同年株式会社博報堂入 社 、マーケテイング部門において、リサーチやマーケティ ングプランニング業務に従事 . 2003 年末来洞察を通した 企業のコンサルティングを行う博報堂フォーサイトに創設 メンバーとして参画. 2004〜2005 年生活総研にも研究員 として兼務、現在，博報堂フォーサイトを前身とする博報 堂イノベーションラボに所属. 未来洞察, ディマンドサイ ド・イノベーション業務や研究などに従事。

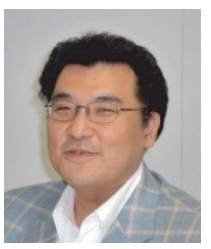

\section{植田 一博(正会員)}

1988 年東京大学教養学部卒業. 1993 年東京大学大学院総 合文化研究科博士課程修了. 博士 (学術). 東京大学大学 院総合文化研究科助手, 助教授, 准教授, 教授を経て, 現 在, 東京大学大学院情報学環教授、創造性研究, 熟達化研 究, 日本伝統芸能の技の分析, 行動経済学, アニマシー知 覚研究, 錯覚研究などに従事. 第 7 回ドコモ・モバイル. サイエンス賞・奨励賞 (2008 年), 日本認知科学会論文賞 (2004 年, 2007 年) などを受賞. 日本認知科学会, 日本 心理学会, 行動経済学会, 電子情報通信学会, 社会情報学会, Cognitive Science Society 各会員. 